\title{
INVESTIGATION OF CORROSION BEHAVIOUR OF IRON IN FOUR DIFFERENT ORGANIC ACIDS
}

\author{
*Mikail Adam Yahaya, Bishir Usman and Muhammad Bashir Ibrahim \\ Department of Pure and Industrial Chemistry, Faculty of Physical Science \\ Bayero University, Kano, P.M.B 3011, \\ ${ }^{*}$ Corresponding author: mikailkbt2@gmail.com,
}

\section{ABSTRACT}

The corrosion behaviour of iron in four different organic acid have been investigated using weight loss method. The acids used includes succinic, formic, maleic and citric acid. The results of the corrosion rates of iron in $\mathrm{C}_{4} \mathrm{H}_{4} \mathrm{O}_{4}, \mathrm{C}_{4} \mathrm{H}_{6} \mathrm{O}_{4}, \mathrm{HCOOH}$ and $\mathrm{C}_{6} \mathrm{H}_{8} \mathrm{O}_{7}$ are 1.125, 1.100, 0.800 and $0.500 \mathrm{mg} \mathrm{cm}^{-2} \mathrm{~h}^{-1}$ respectively. The rate of corrosion increases with increasing concentration of acid and with increase in temperature. The study shows that the rate of corrosion follows the order of reactivity $\mathrm{C}_{4} \mathrm{H}_{4} \mathrm{O}_{4}>\mathrm{C}_{4} \mathrm{H}_{6} \mathrm{O}_{4}>\mathrm{HCOOH}>\mathrm{C}_{6} \mathrm{H}_{8} \mathrm{O}_{7}$.

Keyword: Iron, weight loss, corrosion rate.

\section{INTRODUCTION}

Corrosion is defined as the destruction or deterioration of material because of reaction with its environment which is often restricted to metals but the corrosion engineers consider both metals and non-metals (Venkatachalam et al., 2011). Corrosion attack infrastructures such as bridges, pipelines, vehicles, utilities (electrical, water, telecommunications, and nuclear power plant), engineering and manufacturing, chemical industry, and the oil and gas industry (Ugi et al., 2017). However, the acids responsible for metal surface corrosion through acid attack mechanisms, resulting in millions of dollars being spent annually on maintenance. It is reported that, with proper corrosion prevention techniques, $25-30 \%$ of maintenance costs can be avoided (Isam et al., 2018). Corrosion of metal is an electro-chemical reaction between the metal and its environment in which the metal revert to iron oxide (Usman et al., 2015). The electrochemical process causes a gradual alteration or wearing away of the metal surface and since the process returns the metal to its stable thermodynamic state, the action is considered as a degradation of the material (Wang and Zhang 2011). Corrosion of metal components has been recognized as a major problem in many engineering applications, due to failure of engineering systems such as brittle fracture and fatigue (Hurlen et al., 2013). Iron is known to be the best preferred materials for industry as it has many industrial applications, Because It is easy availability, excellent physical properties, stronger and more workability, low cost, uncomplicated fabrication made it to use in different applications like pipeline materials in oil and gas industry water pipe lines (Noor et al., 2008 ). The corrosive nature of acids also has its applications include chemical cleaning and processing, acid treatment of oil wells and other applications (Soltani et al.,2016 ). To control the corrosion, good understanding of the effect of operating conditions such as different types of acids, concentrations and different heat treatment procedures on the corrosion behavior is required (Umuran et al., 2015). In addition different environment and other tend to effect the corrosion of iron. Many studies have been reported in the corrosion rate of various organic acids in different environment (Musa and Ghoneium 2012). But yet here is not full investigation on the corrosion behaviour of iron in organic acid containing carbonyls, carboxylic acid functional groups. Therefore, in this study corrosion rate of iron in succinic acid, maleic acid, citric acid and formic acid was studied at different concentration and temperature using weight loss method.

\section{MATERIAL AND METHODS}

Materials and Methods

Iron sheets (Fe 99\% purity) was obtained from Metal Focus Fabrication Technology incubation Canter Complex, Kano State Nigeria .Each sheet was press cut in $2 \mathrm{~cm} \times 2 \mathrm{~cm} \times 0.1 \mathrm{~cm}$ dimensions. The iron coupons were polished with 240,620, 800 and 1000 grade of different emery paper. The coupons were degreased in ethanol and dried in acetone, kept in desiccator prior to use.

\section{Corrosive Media Preparation}

A stock solution of Succinic acid $(97 \%, 1.56 \mathrm{~g} / \mathrm{cm}$ ${ }^{3}$ ), maleic acid $\left(99 \% 1.59 \mathrm{~g} / \mathrm{cm}^{3}\right)$, citric acid $\left(99 \%, 1.67 \mathrm{~g} / \mathrm{cm}^{3}\right)$, and formic acid $(96 \%, 1.22$ $\mathrm{g} / \mathrm{cm}^{3}$ ) where prepared by using double distilled water. 
The acid solutions of required concentrations of $0.1,0.2,0.3,0.4,0.5$ and $0.6 \mathrm{M}$ were prepared by appropriate dilutions.

\section{Weight loss Measurement}

During the weight loss experiments, the weight of iron coupon was weight $\left(\mathrm{W}_{1}\right)$ and suspended completely in $0.1-0.6 \mathrm{M}$ solutions of different acid in $100 \mathrm{ml}$ beaker containing $50 \mathrm{ml}$ of acids solution. The coupons were retrieved after 30 , $60,90,120,150$ and $180 \mathrm{~min}$, washed with distilled water dried in acetone and reweighed $\left(W_{2}\right)$. Similarly the effect of temperature was studied by immersion the prepared weighted iron coupon in $0.6 \mathrm{M}$ corrodent concentration at $308,313,318,323$ and $328 \mathrm{~K}$ for $3 \mathrm{hrs}$. The difference in weight and corrosion rate was calculated using equation 1 and 2 respectively. $\Delta \mathrm{W}=\mathrm{W}_{1}-\mathrm{W}_{2}$

(1)

Where $\Delta \mathrm{W}$ is the difference in weight

$W_{1}$ and $W_{2}$ are the weight loss of the coupon before and after immersion.
Corrosion rate $\left(\mathrm{mg} \mathrm{cm}^{-2} \mathrm{~h}^{-1}=\right.$ weight loss / (Area $x$ Time)

$C_{R}=\frac{\Delta W}{A t}$

(2)

Corrosion rate $\left(\mathrm{mg} \mathrm{cm}^{-2} \mathrm{~h}^{-1}=\right.$ weight loss / (Area $x$ Time).

Where $C_{R}=$ Corrosion rate, $\Delta W=$ weight loss in gram, $A=$ Exposed Surface area of coupons, $t=$ time.

\section{RESULTS AND DISCUSSION}

The Effect of Immersion Time

The result presented in Table 1 shows that the weight loss of iron in $\mathrm{C}_{4} \mathrm{H}_{6} \mathrm{O}_{4}, \mathrm{C}_{4} \mathrm{H}_{4} \mathrm{O}_{4}, \mathrm{C}_{6} \mathrm{H}_{8} \mathrm{O}_{7}$ and $\mathrm{HCOOH}$ increased with increase in immersion time. the weight loss of $\mathrm{C}_{4} \mathrm{H}_{6} \mathrm{O}_{4}$, $\mathrm{C}_{4} \mathrm{H}_{4} \mathrm{O}_{4}, \mathrm{C}_{6} \mathrm{H}_{8} \mathrm{O}_{7}$ and $\mathrm{HCOOH}$ at least immersion time of $30 \mathrm{~min}$ are $0.0005,0.0005,0.0004$ and $0.0023 \mathrm{~g}$, but at highest of $3 \mathrm{hrs}$ the weight loss increased to $0.0083,0.0088,0.0053$ and $0.0080 \mathrm{~g}$.

Table 1: Weight loss of iron Corrosion at Different Immersion Time

\begin{tabular}{|c|c|c|c|c|}
\hline \multirow{2}{*}{ Time (min) } & \multicolumn{4}{|c|}{ Weight Loss(g) } \\
\cline { 2 - 5 } & $\mathrm{C}_{4} \mathrm{H}_{6} \mathrm{O}_{4}$ & $\mathrm{C}_{4} \mathrm{H}_{4} \mathrm{O}_{4}$ & $\mathrm{C}_{6} \mathrm{H}_{8} \mathrm{O}_{7}$ & $\mathrm{HCOOH}$ \\
\hline 30 & 0.0005 & 0.0005 & 0.0004 & 0.0023 \\
60 & 0.0011 & 0.0010 & 0.0011 & 0.0035 \\
90 & 0.0015 & 0.0018 & 0.0015 & 0.0047 \\
120 & 0.0020 & 0.0022 & 0.0016 & 0.0060 \\
150 & 0.0022 & 0.0024 & 0.0020 & 0.0069 \\
180 & 0.0083 & 0.0088 & 0.0053 & 0.0080 \\
\hline
\end{tabular}

The Effect of Concentration

The result presented in table 2 shows that the weight loss and the corrosion increases with increase in acids concentration. At the lowest concentration of $0.1 \mathrm{M}$ the weight loss and corrosion rate of iron in $\mathrm{C}_{4} \mathrm{H}_{6} \mathrm{O}_{4}, \mathrm{C}_{4} \mathrm{H}_{4} \mathrm{O}_{4}, \mathrm{C}_{6} \mathrm{H}_{8} \mathrm{O}_{7}$ and $\mathrm{HCOOH}$ are $(0.0008,0.0016,0.0018$ and
$0.0050 \mathrm{~g})$ and $(0.0666,0.1333,0.1500$ and $\left.0.4166 \mathrm{mg} \mathrm{cm}^{-2} \mathrm{~h}^{-1}\right)$. While at highest acid concentration of $0.6 \mathrm{M}$ the weight loss and corrosion rate increased to $(0.0132,0.0135$, 0.0060 and $0.0096 \mathrm{~g})$ and $(1.1000,1.1250$, 0.5000 and $0.8000 \mathrm{mg} \mathrm{cm}^{-2} \mathrm{~h}^{-1}$ )

Table 2: Corrosion rate of Iron at Different Acids Concentration

\begin{tabular}{|c|c|c|c|c|c|c|c|c|}
\hline $\left.\begin{array}{c}\text { Concentration } \\
(\text { mold m }\end{array}{ }^{-3}\right)$ & \multicolumn{5}{|c|}{ Weight Loss (g) } & \multicolumn{4}{c|}{ Corrosion Rate $\left(\mathrm{mg} \mathrm{cm}^{-2} \mathrm{~h}^{-1}\right)$} \\
\cline { 2 - 8 } & $\mathrm{C}_{4} \mathrm{H}_{6} \mathrm{O}_{4}$ & $\mathrm{C}_{4} \mathrm{H}_{4} \mathrm{O}_{4}$ & $\mathrm{C}_{6} \mathrm{H}_{8} \mathrm{O}_{7}$ & $\mathrm{HCOOH}$ & $\mathrm{C}_{4} \mathrm{H}_{6} \mathrm{O}_{4}$ & $\mathrm{C}_{4} \mathrm{H}_{4} \mathrm{O}_{4}$ & $\mathrm{C}_{6} \mathrm{H}_{8} \mathrm{O}_{7}$ & $\mathrm{HCOOH}$ \\
\hline 0.1 & 0.0008 & 0.0016 & 0.0018 & 0.0050 & 0.06666 & 0.1333 & 0.1500 & 0.4166 \\
0.2 & 0.0016 & 0.0058 & 0.0026 & 0.0058 & 0.1333 & 0.4833 & 0.2166 & 0.4833 \\
0.3 & 0.0023 & 0.0102 & 0.0029 & 0.0076 & 0.1916 & 0.8500 & 0.2416 & 0.6333 \\
0.4 & 0.0027 & 0.0127 & 0.0038 & 0.0079 & 0.2250 & 1.0166 & 0.3166 & 0.6583 \\
0.5 & 0.0041 & 0.0132 & 0.0041 & 0.0083 & 0.3416 & 1.0583 & 0.3416 & 0.6916 \\
0.6 & 0.0132 & 0.0135 & 0.0060 & 0.0096 & 1.1000 & 1.1250 & 0.5000 & 0.8000 \\
\hline
\end{tabular}

The Effect of Temperature

The results for the temperature effect were shown in Table 3, it can be seen from the result the weight loss and corrosion rate increases with increase in temperature. At the lower temperature value $(303 \mathrm{~K})$, the weight loss and corrosion rate of iron in $\mathrm{C}_{4} \mathrm{H}_{6} \mathrm{O}_{4}, \mathrm{C}_{4} \mathrm{H}_{4} \mathrm{O}_{4}, \mathrm{C}_{6} \mathrm{H}_{8} \mathrm{O}_{7}$ and $\mathrm{HCOOH}$ are $(0.0031,0.0048,0.0041$ and $0.0041 \mathrm{~g})$ and $(0.2583,0.4000,0.3416$ and $0.3416 \mathrm{mg} \mathrm{cm}^{-2} \mathrm{~h}^{-1}$ ). At higher temperature value of $328 \mathrm{~K}$ the weight loss and corrosion rate increased to $(0.0102,0.0400,0.0210$ and $0.0227 \mathrm{~g})$ and $(0.8500,3.3333,1.7500$ and $\left.1.8917 \mathrm{mg} \mathrm{cm}^{-2} \mathrm{~h}^{-1}\right)$. 
Table 3: Corrosion rate of iron in Acid at Different Temperature

\begin{tabular}{|c|c|c|c|c|c|c|c|c|}
\hline $\begin{array}{c}\text { Temperature } \\
(\mathrm{K})\end{array}$ & \multicolumn{4}{|c|}{ Weight Loss (g) } & \multicolumn{4}{c|}{ Corrosion Rate $\left(\mathrm{mg} \mathrm{cm}^{-2} \mathrm{~h}^{-1}\right)$} \\
\cline { 2 - 8 } & $\mathrm{C}_{4} \mathrm{H}_{6} \mathrm{O}_{4}$ & $\mathrm{C}_{4} \mathrm{H}_{4} \mathrm{O}_{4}$ & $\mathrm{C}_{6} \mathrm{H}_{8} \mathrm{O}_{7}$ & $\mathrm{HCOOH}$ & $\mathrm{C}_{4} \mathrm{H}_{6} \mathrm{O}_{4}$ & $\mathrm{C}_{4} \mathrm{H}_{4} \mathrm{O}_{4}$ & $\mathrm{C}_{6} \mathrm{H}_{8} \mathrm{O}_{7}$ & $\mathrm{HCOOH}$ \\
\hline 303 & 0.0031 & 0.0048 & 0.0041 & 0.0041 & 0.2583 & 0.4000 & 0.3416 & 0.3416 \\
308 & 0.0034 & 0.0151 & 0.0116 & 0.0090 & 0.2833 & 1.2583 & 0.9666 & 0.7500 \\
313 & 0.0040 & 0.0232 & 0.0122 & 0.0126 & 0.3333 & 1.9333 & 1.0166 & 1.0500 \\
318 & 0.0051 & 0.0251 & 0.0156 & 0.0132 & 0.4250 & 2.0916 & 1.3000 & 1.1000 \\
323 & 0.0093 & 0.0308 & 0.0181 & 0.0195 & 0.7750 & 2.5666 & 1.5080 & 1.6250 \\
328 & 0.0102 & 0.0400 & 0.0210 & 0.0227 & 0.8500 & 3.3333 & 1.7500 & 1.8917 \\
\hline
\end{tabular}

\section{Conclusions}

Based on the results obtained from weight loss measurements conclusions are made in this study; weight loss increases with increase of the time of dissolution of iron in all given acid

\section{REFERENCES}

Hurlen, T.M., Park, J. K., Bontoux, L., Jenkins D. and Selleck, W. (2013). Corrosion inhibition of carbon steel using $\mathrm{N}-(2-(2-$ mercaptoacetoxy)- $\mathrm{N}, \mathrm{N}$-dimethyl dodecan-1-aminium bromide. Journal of Corrosion Science. 110-122.

Isam, A., Robert, J., Mohammed, A., Moayed, A., Farzad, D. and Ibrahim, H. (2018). Crude Glycerol as an Innovative Corrosion Inhibitor. Journal of Applied System Innovation.

Musa, A. and Ghoneium, A. F. (2012).Electrochemical corrosion inhibition of Al-alloy in phosphoric acid. Chemistry and Material Resources. 2 (1): 41-55.

Ugi, B. U. and Magu, T. O. (2017). Inhibition, Adsorption and Thermodynamic Investigation of Iron Corrosion by Green Inhibitors in Acidic Medium. linternational Journal of Science \& Technology.

Venkatachalam, A., Memon, S. and Abdul K. (2011). Corrosion study of iron and copper metals and brass alloy in different medium. Journal of Electrochemistry. 8(1): 344-348. medium. The corrosion rate increases as the concentration and temperature increases. The result was found to follow the order of reactivity $\mathrm{C}_{4} \mathrm{H}_{4} \mathrm{O}_{4}>\mathrm{C}_{4} \mathrm{H}_{6} \mathrm{O}_{4}>\mathrm{HCOOH}>\mathrm{C}_{6} \mathrm{H}_{8} \mathrm{O}_{7}$.

Wang, B. and Zhang, C.J (2011). Electrochemical and surface analysis studies on corrosion inhibition studies of mild steel by imidazole derivatives against $\mathrm{CO}_{2}$ Corrosion. International Journal of Scientific and Technology.

Usman, B. Maroof ,H., Abdullah.,Jamaludeen R., Mohammed N.H., (2015); Theoretical and Experimental studies of corrosion inhibition of thiophene-2ethyleamine on mild steel in acid media 76,13 ( 7-14) Bayero Journal of pure and applied sciences.

Noor, A and Hassan, A (2008) corrosion behaviour of mild steel in hydrochloric acid. International journal on Electrochemistry and Science.3, 806818.

Soltani,N., Salavati,H., Rasouli, N., Paziresh,M .and Moghadasi, A (2016); Adsorption and corrosion inhibition Effect of Schiff Base Ligands on low carbon steel Corrosion in Hydrochloric Acid solution. Chemical Engineering Communication, 203:840-854

(Umuran, S.A (2015), Inhibition of aluminium and mild steel in acid media using Gini Arabic cellulose:751-761. 